\title{
Ficus deltoidea ameliorates biochemical, hormonal, and histomorphometric changes in letrozole-induced polycystic ovarian syndrome rats
}

\author{
Muhammad Aliff Haslan', Nurdiana Samsulrizal ${ }^{1 *}$, Nooraain Hashim ${ }^{1}$, Noor Syaffinaz Noor Mohamad Zin ${ }^{1}$, \\ Farshad H. Shirazi ${ }^{2,3}$ and Yong Meng Goh ${ }^{4}$
}

\begin{abstract}
Background: Insulin resistance and hormonal imbalances are key features in the pathophysiology of polycystic ovarian syndrome (PCOS). We have previously shown that Ficus deltoidea var. deltoidea Jack (Moraceae) can improve insulin sensitivity and hormonal profile in PCOS female rats. However, biological characteristics underpinning the therapeutic effects of F. deltoidea for treating PCOS remain to be clarified. This study aims to investigate the biochemical, hormonal, and histomorphometric changes in letrozole (LTZ)-induced PCOS female rats following treatment with F. deltoidea.
\end{abstract}

Methods: PCOS was induced in rats except for normal control by administering LTZ at $1 \mathrm{mg} / \mathrm{kg} /$ day for 21 days. Methanolic extract of F. deltoidea leaf was then orally administered to the PCOS rats at the dose of 250, 500, or $1000 \mathrm{mg} / \mathrm{kg} /$ day, respectively for 15 consecutive days. Lipid profile was measured enzymatically in serum. The circulating concentrations of reproductive hormone and antioxidant enzymes were determined by ELISA assays. Ovarian and uterus histomorphometric changes were further observed by hematoxylin and eosin (H\&E) staining.

Results: The results showed that treatment with F. deltoidea at the dose of 500 and $1000 \mathrm{mg} / \mathrm{kg} /$ day reduced insulin resistance, obesity indices, total cholesterol, triglycerides, low-density lipoprotein cholesterol (LDL), malondialdehyde (MDA), testosterone, luteinizing hormone ( $(\mathrm{LH})$, and follicle-stimulating hormone (FSH) to near-normal levels in PCOS rats. The levels of high-density lipoprotein cholesterol (HDL), estrogen, and superoxide dismutase (SOD) are also similar to those observed in normal control rats. Histomorphometric measurements confirmed that F. deltoidea increased the corpus luteum number and the endometrial thickness.

Conclusions: F. deltoidea can reverse PCOS symptoms in female rats by improving insulin sensitivity, antioxidant activities, hormonal imbalance, and histological changes. These findings suggest the potential use of $F$. deltoidea as an adjuvant agent in the treatment program of PCOS.

Keywords: Polycystic ovarian syndrome, Ficus deltoidea, Letrozole, Lipid, Antioxidant, Ovary, Uterus

*Correspondence: nurdiana7251@uitm.edu.my

${ }^{1}$ Faculty of Applied Sciences, Universiti Teknologi MARA, 40450 Shah

Alam, Selangor, Malaysia

Full list of author information is available at the end of the article

\section{Background}

Polycystic ovarian syndrome (PCOS) is a chronic endocrine disorder that occurs in women of reproductive age. It is estimated to affect up to $4-12 \%$ of women worldwide [1]. PCOS often develops due to 
an imbalance of reproductive hormones and insulin resistance. The major clinical features of PCOS include ovarian cysts, irregular menstrual cycles, weight gain, and fertility problems [2]. The formation of ovarian cysts can interrupt ovulation and eventually leads to infertility. It is therefore not surprising that the prevalence of infertility in women with PCOS is about 70 to $80 \%$ [3]. PCOS has also been found to increase the risk of miscarriage, anxiety, and depression [4].

Metformin and clomiphene citrate are the common drugs prescribed for women with PCOS [5]. Treatment with metformin and clomiphene citrate improved ovulation and pregnancy rates of infertile patients with PCOS [6]. However, these treatments are significantly less effective in obese women with PCOS. It is important to note that about $40-60 \%$ of women with PCOS are overweight or obese [7]. Metformin and clomiphene citrate treatment are also associated with several adverse effects such as diarrhea, nausea, vaginal/ uterine bleeding, breast tenderness, hot flashes, and abdominal pain [8].

Plants have been used for decades to address human fertility issues, and one of them is Ficus deltoidea or also known as Mas Cotek in Malaysia. F. deltoidea is growing wild in Kelantan, Terengganu, Sabah, Sarawak, and Kalimantan. It has recently been formulated, packaged, and distributed as a tonic tea, tea, and capsules across countries, in addition to being boiled in water for consumption [9]. The methanolic extract of $F$. deltoidea leaf has been reported to be rich in tannins, alkaloids, saponins, phenols, flavones, isoflavones, and flavonoids [10]. The presence of these compounds is beneficial for treating dyslipidemia, diabetes, heart disease, cancer, and infertility cases such as PCOS [11]. The antihypertensive [12], chemopreventive, and chemotherapeutic [13] activities of $F$. deltoidea have indeed been reported in animal studies. F. deltoidea also improved depressive behavior in rats [14]. Our previous studies have demonstrated that $F$. deltoidea is not only capable of promoting fertility in diabetic male rats [15] but also improving hormonal balance in PCOS female rats [16]. We have also shown that $F$. deltoidea increased cognitive performance [17] and attenuated tissue morphology changes by increasing antioxidant activities in diabetic rats $[18$, 19]. To the best of our knowledge, despite past extensive studies, the therapeutic activity of $F$. deltoidea on PCOS rats has not yet been fully elucidated. We presently examine the effects of $F$. deltoidea on the hormonal profile, biochemical parameters, and histological changes in LTZ-induced PCOS in rats to address these gaps in knowledge.

\section{Methods}

\section{Sample collection and identification}

F. deltoidea leaves were purchased from Moro Seri Utama Enterprise, Batu Pahat, Johor, Malaysia in September 2016. Following taxonomic authentication, the leaves sample was deposited at the Herbarium Unit, Universiti Kebangsaan Malaysia, Bangi with a voucher specimen (UKMB40315).

\section{Preparation of $F$. deltoidea methanolic extract}

The leaves of $F$. deltoidea were cleaned with running tap water and air-dried in an air oven at $40^{\circ} \mathrm{C}$. The dried leaves were then ground to obtain a fine brownish powder [20]. For extraction, the powder was macerated with $1 \mathrm{~L}$ of absolute methanol (95\%) for three days at $27^{\circ} \mathrm{C}$ with a ratio of 1:10 [21]. The liquid extract was evaporated under reduced pressure at $40^{\circ} \mathrm{C}$ using a rotary evaporator (Buchi, Switzerland). The dried extract was divided into smaller batches in tightly closed glass jar and stored at $-20^{\circ} \mathrm{C}$ until further use to reduce moisture and contamination.

\section{Selection of doses of $F$. deltoidea extract}

The decoction of $F$. deltoidea is commonly taken twice daily by an adult human, $80-100 \mathrm{~mL}$ each time. This volume intake represents about $25-40 \mathrm{~g}$ of the extract per day as the yield of the hot water extract of $F$. deltoidea approximately $18 \%$ [19]. The dose for the rat was then calculated using the conversion of human equivalent dose (HED) to animal equivalent dose (AED) equation (conversion factor 0.018) based on body surface area [22] as stated below:

$$
\operatorname{AED}(\mathrm{mg} / \mathrm{kg})=\operatorname{HED}(\mathrm{mg} / \mathrm{kg}) \mathrm{X} \text { conversion factor }
$$

Based on this calculation, the possible effective dose of F. deltoidea for a rat is ranging between 450 and $720 \mathrm{mg} /$ $\mathrm{kg}$. A toxicity study done by Farsi et al. [21] demonstrated that the $\mathrm{LD}_{50}$ of the metabolic extract of $F$. deltoidea was greater than $5000 \mathrm{mg} / \mathrm{kg}$. Considering these factors, three doses were selected to access the effectiveness of $F$. deltoidea to alleviate PCOS symptoms. The three-dose levels are $250 \mathrm{mg} / \mathrm{kg}\left(1 / 20\right.$ of $\left.\mathrm{LD}_{50}\right), 500\left(1 / 10\right.$ of $\left.\mathrm{LD}_{50}\right)$, $1000 \mathrm{mg} / \mathrm{kg}\left(1 / 5 \mathrm{LD}_{50}\right)$.

\section{Animals}

Female Sprague-Dawley rats (8 weeks old, $N=36$ ) weighing between 140 and $170 \mathrm{~g}$ were procured from Chenur Sdn. Bhd. Serdang, Selangor. Animals were caged in temperature-controlled steel cages $\left(20-22^{\circ} \mathrm{C}, 55-65 \%\right.$ humidity) with a 12-h light/dark cycle and were feed 
standard rat chow (Gold Coin Holdings, Kuala Lumpur, Malaysia) and water ad libitum. Rats were allowed to acclimatise for ten days before the experiments. Daily vaginal smears were performed on all rats to evaluate the ovarian function as described by Karateke et al. [23]. Changes in ovulation phases were determined by the number of cornified cells, nucleated epithelial cell leukocytes in vaginal smear morphology. The procedures were performed at 09:00-10:00 AM daily to avoid hormonal fluctuations that may interrupt the cycles. Only those experimental rats displaying two consecutive regular 4-day cycles were included in the study.

\section{Induction of PCOS rat model}

Animals were induced to develop PCOS with LTZ at $1 \mathrm{mg} / \mathrm{kg}$ b.wt dissolved in $2 \mathrm{~mL} / \mathrm{kg} /$ day of saline for 21 days [24]. Approximately $0.5 \mathrm{~mL}$ of blood samples were collected before and after PCOS induction from the jugular vein. The samples were centrifuged to obtain serum for testosterone level analysis. Female rats that showed significantly higher levels of testosterone than normal rats with the absence estrus phase in their estrous cycle were selected to represent the PCOS model in this study [25].

\section{Experiment design}

Thirty-six adult female Sprague Dawley rats were randomly assigned into six groups with six rats per each as follows: (i) normal control (NC) received saline at $2 \mathrm{~mL} / \mathrm{kg} /$ day, (ii) PCOS control (PC) received saline at $2 \mathrm{~mL} / \mathrm{kg} /$ day, (iii) PCOS rats treated with clomiphene citrate-treated group at $10 \mathrm{mg} / \mathrm{kg} /$ day (PCC), (iv) PCOS rats treated with $F$. deltoidea at $250 \mathrm{mg} / \mathrm{kg} /$ day group (PFD250), (v) PCOS rats treated with F. deltoidea at $500 \mathrm{mg} / \mathrm{kg} /$ day group (PFD500), and (vi) PCOS rats treated with $F$. deltoidea at $1000 \mathrm{mg} / \mathrm{kg} /$ day group (PFD1000).

Clomiphene citrate (Sigma Chemical Co.) and F. deltoidea extract were suspended in $2 \mathrm{~mL}$ saline. All treatment was administered via oral gavage for 15 consecutive days [26]. Daily vaginal smears were continuously performed to determine the changes in estrous cycles (absence of estrus stage). All rats were sacrificed at the onset of the diestrus phase [27] as the morphology of female reproductive organs is greatly influenced by the stage of estrous cycles [28].

At the end of the experiment, animals were allowed to fast for $12 \mathrm{~h}$. Fasting blood glucose was determined using Accu-check Advantage II Blood Glucose Monitor (Roche Mannheim, Germany, the upper limit of detection $33.3 \mathrm{mM}$ ). Rats were anesthetized with diethyl ether (1.9\%) in a large desiccator. The blood was collected from the abdominal aorta into a plain EDTA red-top tube (BD
Vacutainer, USA). Serum was kept at $-80^{\circ} \mathrm{C}$ for biochemical analysis and hormonal profile. The rats were sacrificed by cutting off the diaphragm. Ovary and uterus were identified, dissected out from the surrounding fats, and measured (weight for ovaries and uteri; length for uteri). The separation of the horns of the uterus from the vagina was done by cutting the uppermost point of the cervix. The right ovary and uterus of each rat were used for antioxidant assay while the left side of these organs was preserved in $10 \%$ formalin for histomorphometric analysis.

\section{Physical parameters measurement}

Pre and post body weight and length of the rats were measured at approximately 16:00 clocks during the experiment. Body mass index (BMI), and Lee index were calculated to estimate obesity in animals. The BMI was calculated by dividing the weight $(\mathrm{g})$ by the length $\left(\mathrm{cm}^{2}\right)$ [29]. Body length was defined as the distance from the nose to the anus of rats. Meanwhile, Lee index for each animal was measured by dividing the cube root of the body weight $(\mathrm{g})$ by the naso-anal length $\left(\mathrm{cm}^{2}\right)$ and multiplying the whole expression by 10,000. Rats were considered obese if Lee index value is higher than 310 [30].

\section{Determination of insulin resistance}

Serum insulin concentrations were quantified by UltraSensitive Rat Insulin ELISA kit (Cloud-Clone Corp., Houston, USA) as described by Nurdiana et al. [17]. Homeostatic Model Assessment Insulin resistance (HOMA-IR) was calculated according to Shen et al. [31] as follows:

$$
\text { HOMA }- \text { IR }=\frac{\text { Fasting Blood Glucose (FBG) } x \text { Fasting Insulin (FINS) }}{405}
$$

\section{Analysis of gonadotropins and steroids hormones}

The levels of serum testosterone $(\mathrm{T})$, estrogen $(\mathrm{E})$, progesterone $(\mathrm{P})$, luteinizing hormone $(\mathrm{LH})$, and folliclestimulating hormone (FSH) were measured using Rats ELISA kits procured from Qayee Biotechnology Co., LTD, Shanghai, China. Each hormone was analysed using different kits according to specific antibodies, Horseradish Peroxidase, and the manufacturer's instructions.

In brief, $10 \mu \mathrm{L}$ of the serum samples were added (Insulin: $10 \mu \mathrm{L}$, Progesterone: $10 \mu \mathrm{L}$, Testosterone: $10 \mu \mathrm{L}$, Estrogen: $10 \mu \mathrm{L}$ ) into respective pre-coated ELISA plates. The plates were incubated for $1 \mathrm{~h}$. After incubation, the plates were washed five times with $350 \mu \mathrm{L}$ of diluted washing liquid for $2 \mathrm{~min}$. $50 \mu \mathrm{L}$ of each chromogen A and chromogen $\mathrm{B}$ was further added into each well, gently shaken, and incubated for $10 \mathrm{~min}$. at $37^{\circ} \mathrm{C}$ in a dark room as the chromogen is very sensitive to light and may 
cause sample contamination. Then, $50 \mu \mathrm{L}$ of Stop solution was added to each well to stop the reaction indicated by a change of colour from blue to yellow. The optical density (OD) was then read at $450 \mathrm{~nm}$ wavelength within $15 \mathrm{~min}$. After the stop solution was added. A standard curve was constructed by plotting a graph of the absorbance of each reference standard against its corresponding levels and used to determine each of the hormone levels.

\section{Measurement of serum lipid}

The levels of total cholesterols (TC), triglycerides (TG), low-density lipoprotein cholesterol (LDL), and high-density lipoprotein cholesterol (HDL) were determined using an automatic analyser (Hitachi 911, Boehringer-Mannheim, Germany).

\section{Measurement of antioxidant and oxidative stress biomarkers}

Serum samples were used to assay the activities of antioxidant enzymes, MDA concentrations, and total protein. Bradford method was used to assess the protein concentration in supernatants, with bovine serum albumin as the reference (Sigma Aldrich, St. Louis, MO, USA, Cat. No. B6916).

\section{Histology analysis}

The histological procedures involved in this study were conducted according to the methods mentioned by Mvondo et al. [32]. Ovary and uterus of rats were immersed and fixed in formalin (10\%) solution for at least $48 \mathrm{~h}$ at room temperature. The selected organs were embedded in paraffin wax, sectioned at 5- $\mu \mathrm{m}$ using Leica RM2245 microtome (Leica Biosystems, Wetzlar, Germany), and air-dried in a vertical position. Ten serial sections of each sample were collected for H\&E staining. Histomorphological changes were assessed on microphotographs using a DP70 digital light microscope system (Olympus, Tokyo, Japan) equipped with a camera. The captured image was transferred and analysed with the ImageJ software. Corpus luteum was identified as large, round or irregular glandular structures composed of multiple layers of large granulosa lutein cells. Ovarian cysts were identified as cyst-like structures within the ovary lined by a thin layer of degenerating granulosa cells. Follicles containing an oocyte with a nucleus were counted and described as healthy [23].

\section{Statistical analysis}

All data were expressed as mean \pm standard error of the mean (SEM), except data of the estrous cycle. All measurements were assessed for normality using the Kolmogorov-Smirnov test. The unpaired Student t-test was used to compare the initial and final physical parameters. Oneway analysis of variance (ANOVA) followed by Duncan multiple comparison post hoc tests was performed to elucidate the statistical differences between the experimental groups. Differences were considered significant at $p<0.05$.

\section{Results}

\section{Physical parameters}

Table 1 shows the changes in body weight, BMI, and Lee index values during the experimental period. It is noticeable that oral administration of LTZ $(1 \mathrm{mg} / \mathrm{kg} /$ day) for 21 days to female rats resulted in a significant increase in body weights, BMI, and Lee index values. Higher body weights and Lee index values were maintained in the PC groups throughout the study. Treatment with clomiphene

Table 1 Changes in body weight (g), BMI $\left(\mathrm{g} / \mathrm{cm}^{2}\right)$, and LI value of female PCOS rats

\begin{tabular}{|c|c|c|c|c|c|c|}
\hline Groups & $\begin{array}{l}\text { Initial } \\
\text { Body weight (g) }\end{array}$ & $\begin{array}{l}\text { Final } \\
\text { Body weight (g) }\end{array}$ & $\begin{array}{l}\text { Initial } \\
\text { BMI }\left(\mathrm{g} / \mathrm{cm}^{2}\right)\end{array}$ & $\begin{array}{l}\text { Final } \\
\text { BMI } \\
\left(\mathrm{g} / \mathrm{cm}^{2}\right)\end{array}$ & $\begin{array}{l}\text { Initial } \\
\text { Lee's Index }\end{array}$ & $\begin{array}{l}\text { Final } \\
\text { Lee's Index }\end{array}$ \\
\hline $\mathrm{NC}$ & $\begin{array}{l}200.01 \\
\pm 5.38^{a}\end{array}$ & $\begin{array}{l}218.66 \\
\pm 5.27^{a}\end{array}$ & $\begin{array}{l}0.48 \\
\pm 0.01^{a}\end{array}$ & $\begin{array}{l}0.47 \\
\pm 0.01^{\mathrm{a}}\end{array}$ & $\begin{array}{l}283.15 \\
\pm 3.97^{\mathrm{a}}\end{array}$ & $\begin{array}{l}281.52 \\
\pm 2.21^{a}\end{array}$ \\
\hline$P C$ & $\begin{array}{l}268.25 \\
\pm 9.67^{b, x}\end{array}$ & $\begin{array}{l}298.28 \\
\pm 7.33^{c, y}\end{array}$ & $\begin{array}{l}0.57 \\
\pm 0.02^{b}\end{array}$ & $\begin{array}{l}0.59 \\
\pm 0.02^{c}\end{array}$ & $\begin{array}{l}317.10 \\
\pm 3.95^{b}\end{array}$ & $\begin{array}{l}311.43 \\
\pm 6.31^{c}\end{array}$ \\
\hline PCC & $\begin{array}{l}261.35 \\
\pm 5.39^{b}\end{array}$ & $\begin{array}{l}272.15 \\
\pm 5.81^{b}\end{array}$ & $\begin{array}{l}0.57 \\
\pm 0.03^{b}\end{array}$ & $\begin{array}{l}0.55 \\
\pm 0.02^{b, c}\end{array}$ & $\begin{array}{l}299.83 \\
\pm 1.93^{b}\end{array}$ & $\begin{array}{l}301.35 \\
\pm 3.54^{a, b}\end{array}$ \\
\hline PFD250 & $\begin{array}{l}260.85 \\
\pm 3.47^{b}\end{array}$ & $\begin{array}{l}268.97 \\
\pm 6.57^{b}\end{array}$ & $\begin{array}{l}0.56 \\
\pm 0.01^{b}\end{array}$ & $\begin{array}{l}0.55 \\
\pm 0.03^{b, c}\end{array}$ & $\begin{array}{l}297.27 \\
\pm 2.28^{b}\end{array}$ & $\begin{array}{l}297.99 \\
\pm 5.94^{\mathrm{b}}\end{array}$ \\
\hline PFD500 & $\begin{array}{l}260.44 \\
\pm 2.04^{b}\end{array}$ & $\begin{array}{l}270.78 \\
\pm 5.53^{b}\end{array}$ & $\begin{array}{l}0.58 \\
\pm 0.02^{b, x}\end{array}$ & $\begin{array}{l}0.52 \\
\pm 0.02^{a, b, y}\end{array}$ & $\begin{array}{l}303.85 \\
\pm 5.17^{b, x}\end{array}$ & $\begin{array}{l}284.58 \\
\pm 3.89^{a, b, y}\end{array}$ \\
\hline PFD1000 & $\begin{array}{l}267.42 \\
\pm 6.62^{b}\end{array}$ & $\begin{array}{l}268.42 \\
\pm 4.67^{b}\end{array}$ & $\begin{array}{l}0.57 \\
\pm 0.03^{b, x}\end{array}$ & $\begin{array}{l}0.51 \\
\pm 0.02^{a, b, y}\end{array}$ & $\begin{array}{l}298.03 \\
\pm 4.49^{b, x}\end{array}$ & $\begin{array}{l}278.73 \\
\pm 3.40^{a, y}\end{array}$ \\
\hline
\end{tabular}

Values are mean \pm 1 SD for six rats in each group. Values with different superscripts ${ }^{\mathrm{a}, \mathrm{b}, \mathrm{c}, \mathrm{d}}$ in a column differed significantly at $\mathrm{p}<0.05$ due to treatment effects. Values with different supercripts ${ }^{x, y}$ in a row differed significantly at $p<0.05$ due to time effects 
citrate and $F$. deltoidea extract significantly prevented the body weight gain and elevation of Lee Index values in PCOS rats. However, a significant reduction in BMI and Lee Index values was only observed in the PFD500 and PFD1000 groups.

\section{Estrous cycle}

Figure 1 illustrates the estrous cycle which includes proestrus, estrus, metestrus, and diestrus phases of each experimental group. Animals in the NC group had a regular estrus cycle of 4-5 days throughout the study period. However, the estrous cycle was completely disrupted in all PCOS-like rats and all of them remained mostly at the diestrus or metestrus stages during the induction period (from day 11-31). The PCC, PFD500, and PFD1000 groups displayed improvement in estrous cyclicity from day 32 to 46 (treatment phase). Higher frequency of the estrus phase and less extended diestrus phase were found in comparison to the PC group. Although the PFD250 group showed an improvement in the estrous cyclicity, the presence of an extended diestrus phase was recorded as well as lack of estrus phase throughout the treatment period.

\section{HOMA-IR analysis}

Table 2 showed the fasting blood glucose (FBG), fasting insulin (FINS), and HOMA-IR values of the experimental groups. The PC group had significantly higher values of FBG, FINS, and HOMA-IR than the NC group. Meanwhile, animals in the PCC group showed a significant reduction of the FBG, FINS, and HOMA-IR values in comparison to the PC group. Similar observations were found in the PFD250, PFD500, and PFD1000 groups.

\section{Hormonal profiles}

As depicted in Table 3, the levels of testosterone, FSH, and LH were increased markedly while the levels of estrogen and progesterone were decreased significantly in the $\mathrm{PC}$ group as compared to the $\mathrm{NC}$ group. However, all hormonal changes were significantly improved to near normal levels following treatment with clomiphene citrate. F. deltoidea improved the hormonal profile of PCOS rats in a dose-dependent manner.

\section{Serum lipid profile}

The levels of total cholesterol, triglycerides, and LDL-C were increased while the HDL-C decreased significantly in the PC group as compared to the NC groups (Table 4). However, the levels of total cholesterol, triglycerides, and LDL-C were significantly decreased and HDL-C was increased to near-normal levels in all treated animals.

\section{Antioxidant and oxidative stress activities}

The serum SOD and GSH-Px levels reduced while the levels of MDA increased significantly $(p<0.05)$ in the PC group as compared to the NC animals (Table 5). Treatment with clomiphene citrate showed a significant improvement in the SOD, GSH-Px, and MDA levels as compared to the PC group. Similarly, SOD and GSH-Px levels were also increased and MDA levels decreased in the PFD500 and PFD1000 groups.

\section{Ovarian Histomorphometric changes}

Transverse sections of ovaries from the NC group showed normal histological morphology with several healthy follicles at different stages of oocyte development and the presence of corpus luteum (Fig. 2). However, fewer numbers of corpus luteum and multiple follicular ovarian cysts were observed in the PC group. The number of corpus luteum was significantly decreased by $56.9 \%$ while total numbers of the cystic follicles significantly increased by $608.3 \%$ in the PC group as compared to the NC group (Table 6). LTZ treatment also resulted in a significant reduction in ovary weight. In contrast, the cystic follicle count was significantly reduced while the numbers of corpus luteum and healthy follicles were significantly increased in all treatment groups.

\section{Uterine Histomorphometric changes}

Figure 3 illustrates the photomicrographs of uterine tissues from each experimental group. Smaller uterus size and endometrial thicknesses were observed in the PC group. Morphometric measurements in the PC group revealed that the length of the uterine, endometrium thickness, and numbers of the endometrial gland, were significantly decreased by $25.9,36.1$, and $47.7 \%$, respectively compared to the NC group (Table 7). However, the PCC, PFD500, and PFD1000 groups displaying an improvement in the histological structures. The endometrium wall and endometrial gland were visible following these treatments. The mean endometrium thickness was normalized in the PFD1000 while treatment with clomiphene citrate normalized the numbers of the endometrial gland in PCOS rats. A significant increase $(p<0.05)$ in uterus weight was also observed in the PCC and PFD1000 groups.

\section{Discussion}

The present study demonstrated that LTZ-induced PCOS rats exhibit the clinical and biochemical characterizations of women with PCOS. In line with previous observations, 

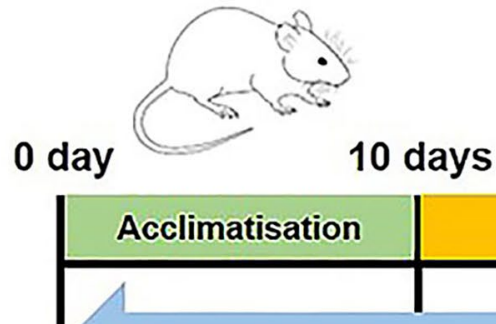

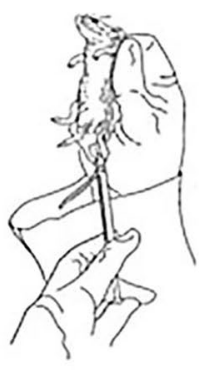

Induction

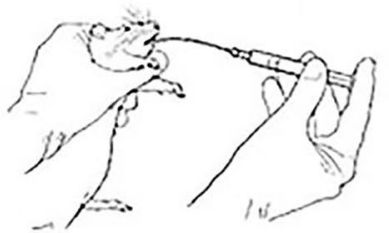

31 days
46 days

\section{Daily vaginal smear}
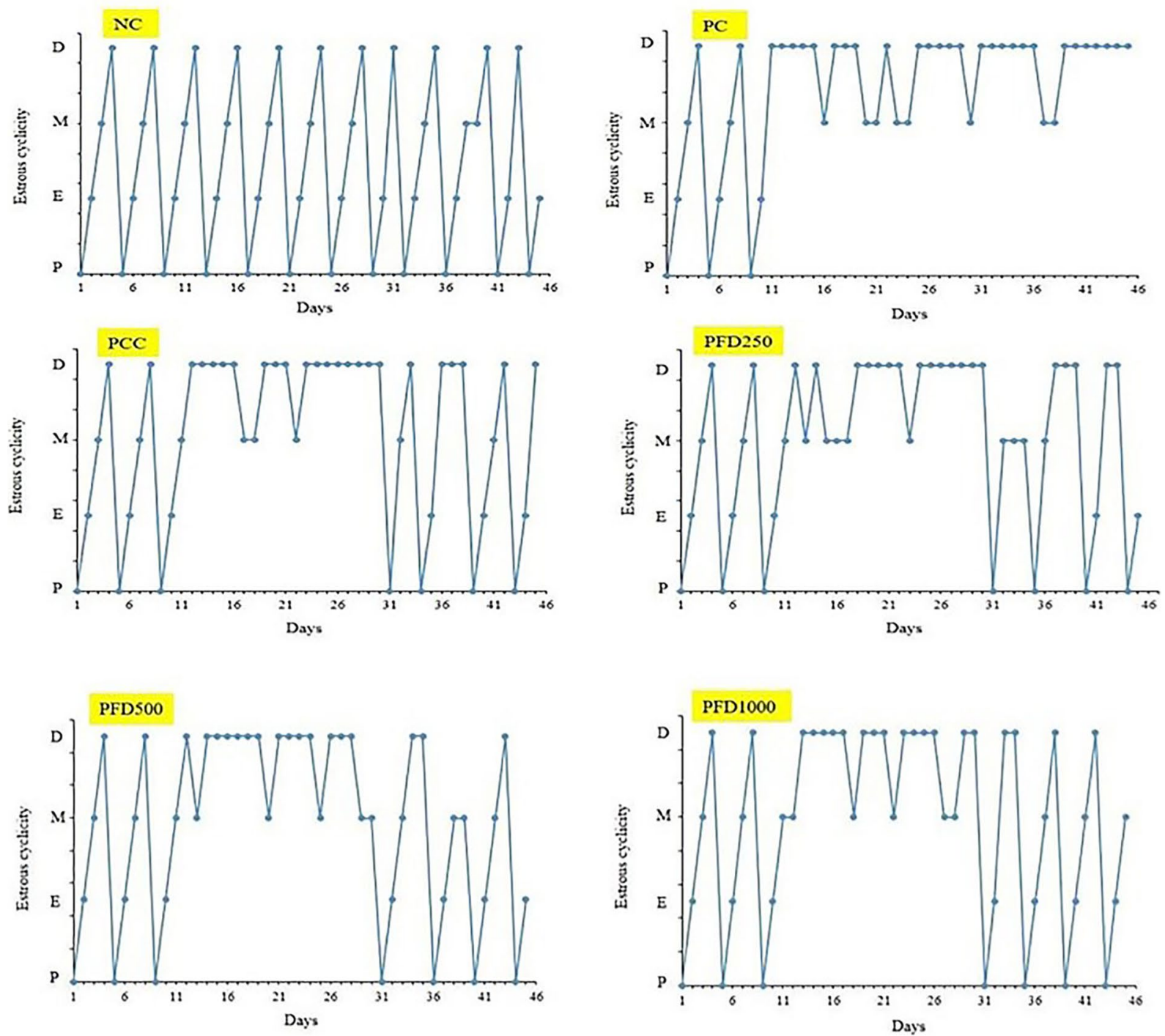

Fig. 1 Phases of the estrous cycle in female rats at different days of treatment. NC: normal control; PC: letrozole-induced PCOS control; PCC: clomiphene citrate; PFD250: $250 \mathrm{mg} / \mathrm{kg} /$ day of F. deltoidea; PFD500: $500 \mathrm{mg} / \mathrm{kg} /$ day of F. deltoidea, and PFD1000: $1000 \mathrm{mg} / \mathrm{kg} /$ day of F. deltoidea. Data show the most represented phase of the estrous cycle in each group, $n=6 . P=$ proestrous, $E=$ estrous, $M=$ metestrus, and $D=$ diestrous 
Table 2 Changes in the levels of FBG, FINS, and HOMA-IR among the experimental groups

\begin{tabular}{|c|c|c|c|c|c|c|}
\hline \multirow[t]{2}{*}{ Parameters } & \multicolumn{6}{|c|}{ Experimental group } \\
\hline & NC & PC & PCC & PFD250 & PFD500 & PFD1000 \\
\hline $\begin{array}{l}\mathrm{FBG} \\
(\mathrm{mg} / \mathrm{dL})\end{array}$ & $\begin{array}{l}103.42 \\
\pm 1.22^{\mathrm{a}}\end{array}$ & $\begin{array}{l}122.82 \\
\pm 6.21^{c}\end{array}$ & $\begin{array}{l}109.01 \\
\pm 3.25^{\mathrm{a}}\end{array}$ & $\begin{array}{l}118.92 \\
\pm 2.85^{b, c}\end{array}$ & $\begin{array}{l}115.06 \\
\pm 1.49^{b, c}\end{array}$ & $\begin{array}{l}114.41 \\
\pm 2.82^{a, b}\end{array}$ \\
\hline $\begin{array}{l}\text { FINS } \\
(\mu \mathrm{U} / \mathrm{mL})\end{array}$ & $\begin{array}{l}1.49 \\
\pm 0.10^{\mathrm{a}}\end{array}$ & $\begin{array}{l}2.69 \\
\pm 0.12^{b}\end{array}$ & $\begin{array}{l}1.68 \\
\pm 0.18^{\mathrm{a}}\end{array}$ & $\begin{array}{l}1.84 \\
\pm 0.14^{\mathrm{a}}\end{array}$ & $\begin{array}{l}1.75 \\
\pm 0.09^{\mathrm{a}}\end{array}$ & $\begin{array}{l}1.65 \\
\pm 0.12^{\mathrm{a}}\end{array}$ \\
\hline HOMA-IR & $\begin{array}{l}1.46 \\
\pm 0.04^{\mathrm{a}}\end{array}$ & $\begin{array}{l}2.09 \\
\pm 0.21^{c}\end{array}$ & $\begin{array}{l}1.64 \\
\pm 0.10^{a, b}\end{array}$ & $\begin{array}{l}1.94 \\
\pm 0.09^{b, c}\end{array}$ & $\begin{array}{l}1.78 \\
\pm 0.04^{a, b}\end{array}$ & $\begin{array}{l}1.79 \\
\pm 0.09^{a, b}\end{array}$ \\
\hline
\end{tabular}

Superscripts ${ }^{a, b, c}$ represent significant difference at $p<0.05$ among the groups within rows

Table 3 The effects of F. deltoidea on hormonal profiles in LTZ-induced PCOS rats

\begin{tabular}{|c|c|c|c|c|c|c|}
\hline \multirow[t]{2}{*}{ Hormones } & \multicolumn{6}{|c|}{ Experimental group } \\
\hline & $\mathrm{NC}$ & $\mathrm{PC}$ & PCC & PFD250 & PFD500 & PFD1000 \\
\hline $\begin{array}{l}\text { Testosterone } \\
(\mathrm{ng} / \mathrm{mL})\end{array}$ & $\begin{array}{l}93.45 \\
\pm 2.26^{\mathrm{a}}\end{array}$ & $\begin{array}{l}119.11 \\
\pm 4.86^{c}\end{array}$ & $\begin{array}{l}93.15 \\
\pm 4.50^{a}\end{array}$ & $\begin{array}{l}110.98 \\
\pm 4.57^{\mathrm{b}, \mathrm{c}}\end{array}$ & $\begin{array}{l}98.64 \\
\pm 4.28^{a, b}\end{array}$ & $\begin{array}{l}94.19 \\
\pm 3.03^{\mathrm{a}}\end{array}$ \\
\hline $\begin{array}{l}\text { Estrogen } \\
(\mathrm{pg} / \mathrm{mL})\end{array}$ & $\begin{array}{l}60.90 \\
\pm 2.33^{b}\end{array}$ & $\begin{array}{l}40.94 \\
\pm 7.59^{a}\end{array}$ & $\begin{array}{l}65.37 \\
\pm 3.43^{b}\end{array}$ & $\begin{array}{l}53.46 \\
\pm 6.11^{a, b}\end{array}$ & $\begin{array}{l}60.19 \\
\pm 5.70^{b}\end{array}$ & $\begin{array}{l}64.69 \\
\pm 4.74^{b}\end{array}$ \\
\hline Progesterone (ng/mL) & $\begin{array}{l}12.49 \\
\pm 0.97^{c}\end{array}$ & $\begin{array}{l}8.55 \\
\pm 0.89^{a}\end{array}$ & $\begin{array}{l}10.13 \\
\pm 0.50^{b, c}\end{array}$ & $\begin{array}{l}9.23 \\
\pm 0.99^{a, b}\end{array}$ & $\begin{array}{l}10.06 \\
\pm 0.47^{b, c}\end{array}$ & $\begin{array}{l}12.15 \\
\pm 0.81^{c}\end{array}$ \\
\hline $\mathrm{FSH}(\mathrm{mIU} / \mathrm{mL})$ & $\begin{array}{l}12.52 \\
\pm 0.91^{\mathrm{a}}\end{array}$ & $\begin{array}{l}18.99 \\
\pm 0.59^{b}\end{array}$ & $\begin{array}{l}13.88 \\
\pm 0.80^{a}\end{array}$ & $\begin{array}{l}14.29 \\
\pm 1.14^{\mathrm{a}}\end{array}$ & $\begin{array}{l}13.90 \\
\pm 1.37^{a}\end{array}$ & $\begin{array}{l}13.14 \\
\pm 0.74^{a}\end{array}$ \\
\hline $\mathrm{LH}(\mathrm{ng} / \mathrm{mL})$ & $\begin{array}{l}24.06 \\
\pm 1.16^{a}\end{array}$ & $\begin{array}{l}38.82 \\
\pm 4.56^{c}\end{array}$ & $\begin{array}{l}30.46 \\
\pm 1.56^{a, b}\end{array}$ & $\begin{array}{l}37.73 \\
\pm 0.85^{c}\end{array}$ & $\begin{array}{l}33.48 \\
\pm 1.90^{\mathrm{b}, \mathrm{c}}\end{array}$ & $\begin{array}{l}29.45 \\
\pm 1.20^{a, b}\end{array}$ \\
\hline
\end{tabular}

Superscripts ${ }^{a, b, c}$ within a row represent significant difference at $p<0.05$ among the groups

Table 4 The effects of F. deltoidea on serum lipid profile in LTZ-induced PCOS rats

\begin{tabular}{|c|c|c|c|c|c|c|}
\hline \multirow[t]{2}{*}{ Lipids Parameters } & \multicolumn{6}{|l|}{ Groups } \\
\hline & NC & $\mathrm{PC}$ & PCC & PFD250 & PFD500 & PFD1000 \\
\hline Total cholesterol (mmol/L) & $\begin{array}{l}1.872 \\
\pm 0.11^{b, c}\end{array}$ & $\begin{array}{l}2.603 \\
\pm 0.10^{d}\end{array}$ & $\begin{array}{l}1.233 \\
\pm 0.10^{a}\end{array}$ & $\begin{array}{l}2.052 \\
\pm 0.06^{c}\end{array}$ & $\begin{array}{l}1.850 \\
\pm 0.10^{b, c}\end{array}$ & $\begin{array}{l}1.742 \\
\pm 0.10^{b}\end{array}$ \\
\hline Triglycerides (mmol/L) & $\begin{array}{l}0.644 \\
\pm 0.05^{\mathrm{a}}\end{array}$ & $\begin{array}{l}1.462 \\
\pm 0.12^{c}\end{array}$ & $\begin{array}{l}0.603 \\
\pm 0.98^{a}\end{array}$ & $\begin{array}{l}1.072 \\
\pm 0.11^{b}\end{array}$ & $\begin{array}{l}0.962 \\
\pm 0.05^{b}\end{array}$ & $\begin{array}{l}0.665 \\
\pm 0.07^{a}\end{array}$ \\
\hline LDL-C (mmol/L) & $\begin{array}{l}0.288 \\
\pm 0.09^{b}\end{array}$ & $\begin{array}{l}0.435 \\
\pm 0.02^{d}\end{array}$ & $\begin{array}{l}0.200 \\
\pm 0.17^{a}\end{array}$ & $\begin{array}{l}0.413 \\
\pm 0.02^{d}\end{array}$ & $\begin{array}{l}0.378 \\
\pm 0.03^{c, d}\end{array}$ & $\begin{array}{l}0.335 \\
\pm 0.02^{b, c}\end{array}$ \\
\hline HDL-C (mmol/L) & $\begin{array}{l}1.572 \\
\pm 0.09^{b}\end{array}$ & $\begin{array}{l}1.227 \\
\pm 0.07^{a}\end{array}$ & $\begin{array}{l}1.547 \\
\pm 0.06^{b}\end{array}$ & $\begin{array}{l}1.553 \\
\pm 0.08^{b}\end{array}$ & $\begin{array}{l}1.588 \\
\pm 0.08^{b}\end{array}$ & $\begin{array}{l}1.550 \\
\pm 0.08^{b}\end{array}$ \\
\hline
\end{tabular}

Superscripts ${ }^{a, b, c, d}$ within a column represent significant difference at $p<0.05$ among the groups

our results showed PCOS-like conditions in rats including an abnormal estrus cyclicity, elevated body weight, insulin resistance, total cholesterol, triglycerides, LDL-C, MDA, LH, FSH, and testosterone levels [33]. The animals also had lower HDL-C, estrogen, progesterone, SOD, and GSH-Px levels than the normal control group. We demonstrated, for the first time, that treatment with $F$. deltoidea at 500 and $1000 \mathrm{mg} / \mathrm{kg} /$ day can ameliorate PCOS symptoms in rats by improving insulin resistance, antioxidant activity, and hormonal balance. We also showed that $F$. deltoidea significantly decreases the number of cystic follicles, increases the number of corpus luteum, and normalizes the endometrium thickness.

Treatment with LTZ to adult rats for 21 days increased body weight, BMI, Lee's index (Table 1), and resulted in disruption of the estrous cycle (Fig. 1). Lee's index values of the PC group were higher than 310 throughout the experimental period, indicating the efficacy of LTZ in the induction of PCOS. A significant increase between the initial and final measurement of BMI further confirms 
Table 5 The effect of $F$. deltoidea on antioxidant enzymes and lipid peroxidation in LTZ-induced PCOS rats

\begin{tabular}{llll}
\hline Groups & \multicolumn{3}{l}{ Antioxidant enzymes and lipid peroxidation levels } \\
\cline { 2 - 4 } & SOD $(\mathbf{U} / \mathbf{m L})$ & GSH-Px (U/L) & TBARS $(\boldsymbol{\mu m o l}, \mathbf{M D A})$ \\
\hline NC & $1.90 \pm 0.15^{\mathrm{b}}$ & $65.47 \pm 1.622^{\mathrm{d}}$ & $1.69 \pm 0.14^{\mathrm{a}}$ \\
PC & $0.78 \pm 0.09^{\mathrm{a}}$ & $40.44 \pm 3.52^{\mathrm{a}}$ & $4.03 \pm 0.34^{\mathrm{c}}$ \\
PCC & $1.66 \pm 0.27^{\mathrm{b}}$ & $52.61 \pm 3.68^{\mathrm{b}, \mathrm{c}}$ & $2.22 \pm 0.37^{\mathrm{a}}$ \\
PFD250 & $0.85 \pm 0.17^{\mathrm{a}}$ & $43.02 \pm 3.31^{\mathrm{a}, \mathrm{b}}$ & $3.43 \pm 0.34^{\mathrm{b}, \mathrm{c}}$ \\
PFD500 & $1.37 \pm 0.24^{\mathrm{a}, \mathrm{b}}$ & $48.58 \pm 2.74^{\mathrm{a}, \mathrm{b}, \mathrm{c}}$ & $2.72 \pm 0.39^{\mathrm{a}, \mathrm{b}}$ \\
PFD1000 & $1.70 \pm 0.29^{\mathrm{b}}$ & $55.27 \pm 5.46^{\mathrm{c}, \mathrm{d}}$ & $2.09 \pm 0.29^{\mathrm{a}}$ \\
\hline
\end{tabular}

Superscripts $a, b, c$ within a column represent significant difference at $p<0.05$ among the groups

the overweight and obesity incidence in PCOS rats. Similar findings have been reported in different animal models of PCOS [34-36]. It is important to note that $F$. deltoidea treatment at 500 and $1000 \mathrm{mg} / \mathrm{kg} /$ day for up to 15 days significantly reduced BMI and Lee's Index values in PCOS rats. A small weight loss of approximately $5 \%$ can improve insulin resistance, hormone levels, menstrual cycles, and infertility associated with PCOS $[37,38]$. Indeed, lower HOMA-IR values were found in the PFD500 and PFD1000 groups (Table 2), suggesting the insulin-sensitizing activity of $F$. deltoidea. Animals in these groups were also associated with improvement in estrous cyclicity during the treatment phase. These findings were consistent with the notion that insulin sensitiser may improve menstrual cyclicity and ovulation in PCOS [39].

We demonstrated that $F$. deltoidea treatment at 500 and $1000 \mathrm{mg} / \mathrm{kg} /$ day significantly reduced the concentrations of testosterone, FSH, and LH as well as increased estrogen and progesterone to near-normal levels in PCOS rats (Table 4). These results imply that $F$. deltoidea exhibited anti-androgenic and estrogenic properties in PCOS rats that in turn can explain the suppression of FSH and LH. A similar finding has been reported by Nur Ajeerah et al. [16]. Supporting this view, the presence of catechin, gallocatechin, and epigallocatechin have been reported by Haida et al. [40]. Catechin is known to suppress appetite, reduce food consumption, and is responsible for the reduction in testosterone level [41, 42].

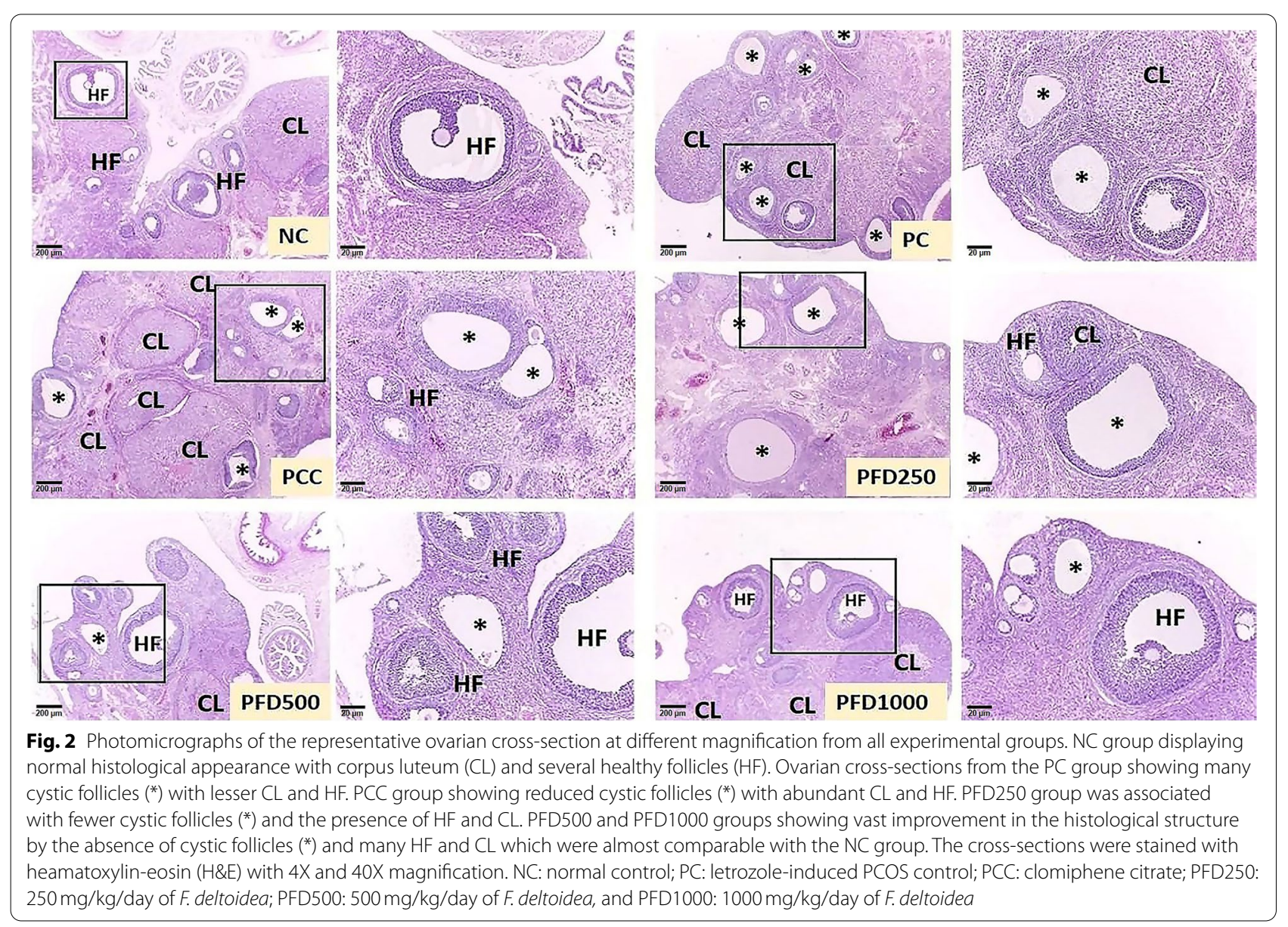


Table 6 Changes of ovarian morphological parameters in all experimental groups

\begin{tabular}{lllll}
\hline Groups & Ovary weight (g) & Total numbers of cystic follicles & Numbers of corpus luteum & $\begin{array}{c}\text { Numbers } \\
\text { of healthy } \\
\text { follicles }\end{array}$ \\
\hline NC & $0.20 \pm 0.02^{\mathrm{b}}$ & $1.20 \pm 0.20^{\mathrm{a}}$ & $5.40 \pm 0.51^{\mathrm{c}, \mathrm{d}}$ & $10.40 \pm 0.50^{\mathrm{c}}$ \\
PC & $0.11 \pm 0.01^{\mathrm{a}}$ & $8.50 \pm 0.43^{\mathrm{e}}$ & $2.33 \pm 0.33^{\mathrm{a}}$ & $4.17 \pm 0.48^{\mathrm{a}}$ \\
PCC & $0.17 \pm 0.02^{\mathrm{b}}$ & $2.17 \pm 0.31^{\mathrm{a}, \mathrm{b}}$ & $6.07 \pm 0.37^{\mathrm{d}}$ & $9.50 \pm 0.62^{\mathrm{c}}$ \\
PFD250 & $0.20 \pm 0.02^{\mathrm{b}}$ & $7.00 \pm 0.36^{\mathrm{d}}$ & $3.17 \pm 0.40^{\mathrm{a}, \mathrm{b}}$ & $4.33 \pm 0.42^{\mathrm{a}}$ \\
PFD500 & $0.20 \pm 0.01^{\mathrm{b}}$ & $2.83 \pm 0.47^{\mathrm{b}}$ & $4.16 \pm 0.60^{\mathrm{b}, \mathrm{c}}$ & $6.33 \pm 0.42^{\mathrm{b}}$ \\
PFD1000 & $0.22 \pm 0.03^{\mathrm{b}}$ & $4.20 \pm 0.37^{\mathrm{c}}$ & $4.20 \pm 0.37^{\mathrm{b}, \mathrm{c}}$ & $7.20 \pm 0.58^{\mathrm{b}}$ \\
\hline
\end{tabular}

Superscripts $^{\mathrm{a}, \mathrm{b}, \mathrm{c}}$ within a column represent significant difference at $p<0.05$ among the groups

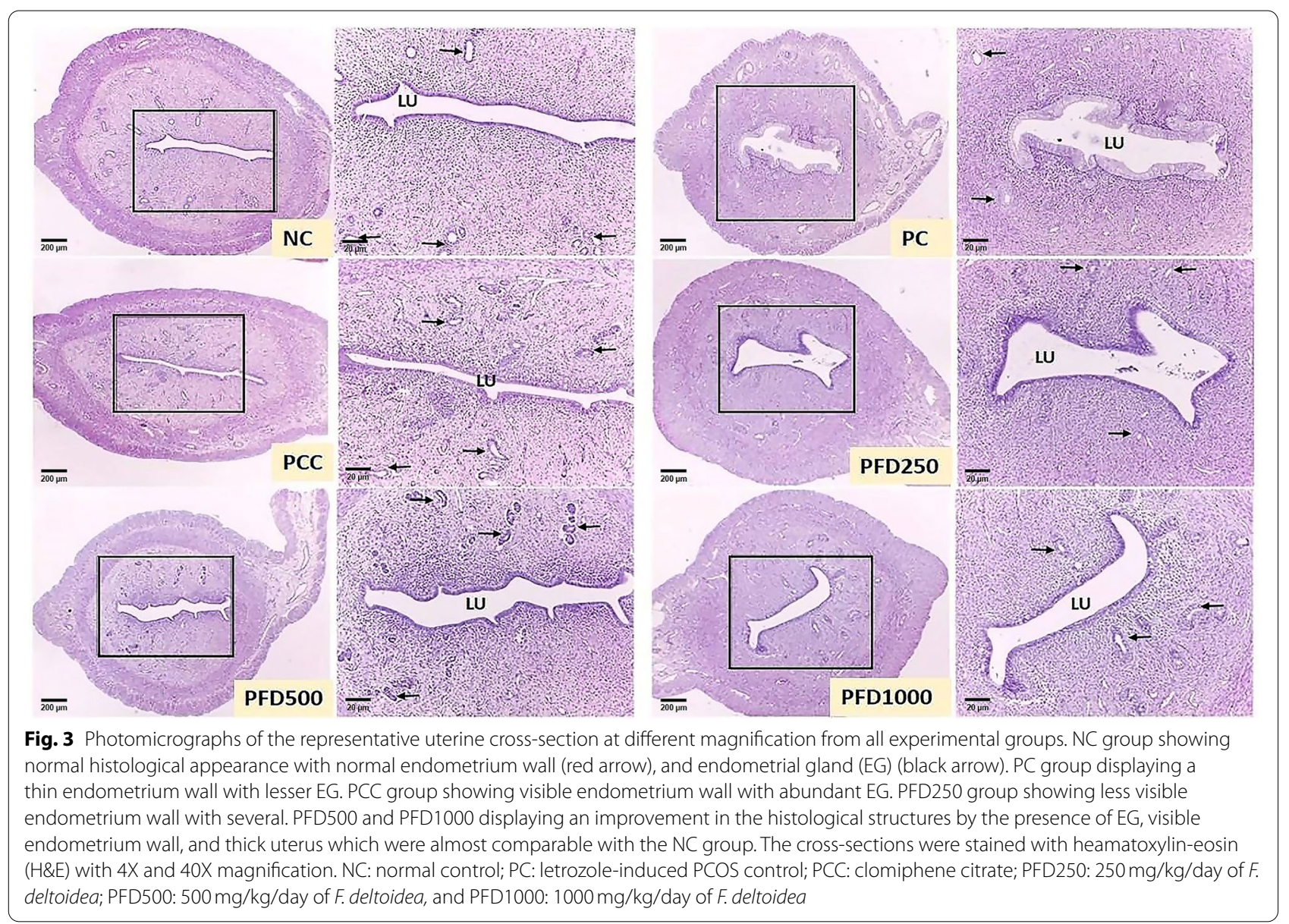

Meanwhile, epigallocatechin and apigenin were proven to inhibit $17 \beta$-HSD, 3 $\beta$-HSD enzymes, and P450 activity that lead to inhibitory effects on testosterone production. However, Rocha et al. [43] demonstrated that normalization of testosterone levels did not improve BMI, glucose, or lipid metabolism in postmenopausal hyperandrogenism rats. It should be mentioned that the effects of serum androgen normalization are different in reproductive and non-reproductive status. It has also been shown that therapy aimed at reducing androgen over-production failed to ameliorate insulin resistance in PCOS [44]. Further analyses are, therefore, needed to assess the biological outcomes following F. deltoidea.

Lipid disturbances are the most common metabolic abnormality in PCOS. Our current results showed that the administration of LTZ for 21 days was not only able to develop PCOS symptoms similar to those occurring in humans but also affect the serum lipid profiles (Table 4). 
Table 7 Changes of uterine morphological parameters in all experimental groups

\begin{tabular}{lllll}
\hline Group & Uterine weight $(\mathbf{g})$ & Uterus Length $(\boldsymbol{\mu m})$ & $\begin{array}{l}\text { Endometrium Thickness } \\
(\boldsymbol{\mu m})\end{array}$ & $\begin{array}{l}\text { Numbers of } \\
\text { Endometrial } \\
\text { gland }(\mathbf{n})\end{array}$ \\
\hline NC & & $183.05 \pm 3.07^{c, d}$ & $135.79 \pm 2.91^{c}$ & $11.80 \pm 0.66^{\mathrm{b}}$ \\
PC & $0.46 \pm 0.03^{\mathrm{b}, c}$ & $135.67 \pm 2.79^{\mathrm{a}}$ & $86.71 \pm 1.43^{\mathrm{a}}$ & $6.17 \pm 0.31^{\mathrm{a}}$ \\
PCC & $0.28 \pm 0.02^{\mathrm{a}}$ & $200.00 \pm 2.79^{\mathrm{d}, \mathrm{e}}$ & $133.07 \pm 2.58^{\mathrm{b}, \mathrm{c}}$ & $12.00 \pm 0.58^{\mathrm{b}}$ \\
PFD250 & $0.44 \pm 0.06^{\mathrm{b}, \mathrm{c}}$ & $158.72 \pm 3.33^{\mathrm{b}}$ & $115.37 \pm 8.13^{\mathrm{b}}$ & $6.67 \pm 0.66^{\mathrm{a}}$ \\
PFD500 & $0.35 \pm 0.02^{\mathrm{a}, \mathrm{b}}$ & $172.25 \pm 2.98^{\mathrm{b}, c}$ & $123.85 \pm 4.91^{\mathrm{b}, \mathrm{c}}$ & $12.50 \pm 0.56^{\mathrm{b}}$ \\
PFD1000 & $0.37 \pm 0.05^{\mathrm{a}, \mathrm{b}, \mathrm{c}}$ & $210.95 \pm 19.75^{\mathrm{e}}$ & $139.80 \pm 11.51^{\mathrm{c}}$ & $14.40 \pm 0.68^{\mathrm{c}}$ \\
\hline
\end{tabular}

Superscripts ${ }^{a, b, c, d, e}$ within rows represent significant difference at $p<0.05$ among the groups

A similar finding has been reported by Ndeingang et al. [45]. Nevertheless, Wasan et al. [46] provide evidence that LTZ did not significantly alter serum lipid profile. This discrepancy can be justified by the fact that LTZ only has a good short-term tolerability profile [47]. Continuous exposure to LTZ has been demonstrated to cause significant changes in lipid profile [48]. It was found that F. deltoidea restored the levels of total cholesterol, triglycerides, LDL-C, and HDL-C to normal levels in PCOS rats that had improvement in hormonal profile and the estrous cycle. The data support that the relationship between lipid profile and sex hormones $[49,50]$. These results are also compatible with earlier studies demonstrating that $F$. deltoidea can reverse the abnormalities in the lipid profile of diabetic rats [51] and adults with pre-diabetes [52],

Lipid peroxidation and antioxidants were further evaluated to understand the potential of $F$. deltoidea in treating PCOS. We found that the PCOS rats had higher serum MDA and lower endogenous antioxidant enzymes (SOD and GSH-Px) levels than normal control (Table 5), indicating oxidant-antioxidant imbalance occurred. A disturbance in the antioxidant-prooxidant balance has been reported to induce pathological consequences in oocyte maturation, ovulation, fertilization, implantation, and embryo development [53]. In contrast, PCOS animals in the PFD500 and PFD1000 groups had a significantly lower level of MDA but higher SOD and GSH-Px activities. These findings in agreement with data which were reported the prospect of oxidative stress modulator-natural antioxidants as therapeutic interventions for managing PCOS [54]. However, an increase in SOD activity has also been reported in women with PCOS [55]. A higher level of SOD activity and reduced levels of glutathione peroxidase has been shown to disrupt the efficiency of ROS scavenging in the follicular environment [56]. Therefore, histomorphometric analysis of the ovary and uterine tissues are required to confirm these results.

PCOS has been demonstrated to induce histo-architectural changes in the ovary [57] and uterus [58] of rats. In agreement with previous studies on PCOS animal models, fewer numbers of corpus luteum and multiple follicular ovarian cysts were observed in the PC group $[59,60]$. Reduction in ovarian weight, uterine length and weight, endometrium thickness, and numbers of the endometrial gland are consistent with decreasing levels of testosterone, FSH, LH, and antioxidants activities. Our study provides additional support for the association between reproductive hormone levels and gonadal morphology in rats with PCOS. Importantly, significant increases in the numbers of corpora lutea, ovarian and uterine weight, endometrium thickness, and numbers of the endometrial gland, together with a decrease in the numbers of cystic follicles were found in the PCC, PFD500, and PFD1000 groups. The appearance of corpora lutea suggest that these animals have ovulated. Higher levels of progesterone obtained in these groups confirmed that ovulation has occurred. It is important to note that the management of PCOS is aimed mainly at restoring ovulation.

Taken together, our results showed that F. deltoidea extract effectively ameliorates biochemical, hormonal, and histomorphometric changes to levels comparable with those reported in the clomiphene citrate-treated rats. It may be suggested that $F$. deltoidea extract promotes adiponectin, a protein hormone that modulates several metabolic processes, including glucose regulation and fatty acid oxidation [61]. These results support the hypothesis that a combination of lipid-lowering with insulin-sensitizing agents would achieve better therapeutic effects in the treatment of PCOS [62]. Therefore, future studies are required to determine the value of serum adiponectin levels in the PCOS rat model.

\section{Conclusion}

We conclude that $F$. deltoidea can reverse the symptoms of PCOS in female rats by improving insulin sensitivity, lipid profile, antioxidant activity, hormonal balance. These findings improve our current understanding of the potential use of $F$. deltoidea for the treatment of PCOS. 


\begin{abstract}
Abbreviations
ANOVA: Analysis of variance; ELISA: Enzyme-linked immunosorbent assay; LTZ: Letrozole; GSH-PX: Glutathione peroxidase enzyme; H\&E: Hematoxylin and eosin; PCOS: Polycystic ovarian syndrome; SOD: Superoxide dismutase enzyme; LDL: Low-density lipoprotein cholesterol; MDA: Malondialdehyde; LH: Luteinizing hormone; FSH: Follicle-stimulating hormone; NC: Normal control; PC: Letrozole-induced PCOS control; PCC: Clomiphene citrate; PFD250: $250 \mathrm{mg} / \mathrm{kg} /$ day of F. deltoidea; PFD500: $500 \mathrm{mg} / \mathrm{kg} /$ day of F. deltoidea; PFD1000: $1000 \mathrm{mg} / \mathrm{kg} /$ day of F. deltoidea.
\end{abstract}

\section{Acknowledgments}

We thank the Faculty of Applied Sciences, Universiti Teknologi MARA for the postoperative care of the animals.

\section{Authors' contributions}

$\mathrm{MAH}, \mathrm{NS}$, and $\mathrm{NH}$ were involved in the design, interpretation, and analysis of data. NS supervised the study and drafted the present article. MAH and NSNMZ performed experimental works; YMG and FHS revised the article critically. All authors read and approved the final manuscript.

\section{Funding}

This research was supported by grants from the Ministry of Higher Education [MOE FRGS: 600-RMI/FRGS 5/3 (325/2019)]. The funding body had no role in the design of the study and collection, analysis, and interpretation of data and in writing the manuscript.

\section{Availability of data and materials}

All data generated or analyzed during this study are included in this manuscript.

\section{Declarations}

\section{Ethics approval and consent to participate}

All animal handling and experimental protocols were performed in strict accordance with the ethics guidelines approved by the Committee on Animal for Research and Ethics, Universiti Teknologi MARA (160/2016). We confirmed that the study was carried out in compliance with the ARRIVE guidelines.

\section{Consent for publication}

Not applicable.

\section{Competing interests}

The authors declare that they have no competing interests.

\section{Author details \\ ${ }^{1}$ Faculty of Applied Sciences, Universiti Teknologi MARA, 40450 Shah Alam, Selangor, Malaysia. ${ }^{2}$ Department of Pharmacology and Toxicology, School of Pharmacy, Shahid Beheshti University of Medical Sciences, Tehran, Iran. ${ }^{3}$ Pharmaceutical Sciences Research Center, Shahid Beheshti University of Medical Sciences, Tehran, Iran. ${ }^{4}$ Department of Veterinary Preclinical Sci- ences, Faculty of Veterinary Medicine, Universiti Putra Malaysia (UPM), Serdang, Malaysia.}

Received: 5 April 2021 Accepted: 24 September 2021

Published online: 29 November 2021

\section{References}

1. Aversa A, La Vignera S, Rago R, Gambineri A, Nappi RE, Calogero AE, et al. Fundamental concepts and novel aspects of polycystic ovarian syndrome: expert consensus resolutions. Front Endocrinol. 2020;11:516. https://doi.org/10.3389/fendo.2020.00516.

2. Strowitzki T. Advanced diagnosis of polycystic ovary syndrome-new prediction models with standard parameters. Fertil Steril. 2021;115(1):92-3. https://doi.org/10.1016/j.fertnstert.2020.09.031.

3. Melo AS, Ferriani RA, Navarro PA. Treatment of infertility in women with polycystic ovary syndrome: approach to clinical practice. Clinics (Sao Paulo, Brazil). 2015;70(11):765-9. https://doi.org/10.6061/clinics/2015(11) 09.
4. Saei Ghare Naz M, Ramezani Tehrani F, Behroozi-Lak T, Mohammadzadeh F, Kholosi Badr F, Ozgoli G. Polycystic ovary syndrome and pelvic floor dysfunction: A narrative review. Res Rep Urol. 2020;12:179-85. https://doi. org/10.2147/RRU.S249611.

5. Leanza V, Coco L, Grasso F, Leanza G, Zarbo G, Palumbo M. Ovulation induction with clomiphene citrate and metformin in women with polycystic ovary syndrome. Minerva Ginecol. 2014;66(3):299-301.

6. Sawant S, Bhide P. Fertility treatment options for women with polycystic ovary syndrome. Clin Med Insights Reprod Health. 2019. https://doi.org/ 10.1177/1179558119890867.

7. Hoeger KM. Obesity in polycystic ovary syndrome: insulin sensitizing therapy. Curr Obes Rep. 2012;1:191-8. https://doi.org/10.1007/ s13679-012-0030-y.

8. Sidra S, Tariq MH, Farrukh MJ, Mohsin M. Evaluation of clinical manifestations, health risks, and quality of life among women with polycystic ovary syndrome. PLoS One. 2019;14:10. https://doi.org/10.1371/journal.pone. 0223329.

9. Bunawan H, Amin NM, Bunawan SN, Baharum SN, Mohd NN. Ficus deltoidea Jack: a review on its phytochemical and pharmacological importance. Evid Based Complement Alternat Med. 2014. https://doi.org/ $10.1155 / 2014 / 902734$.

10. Musapha Z, Harun H. Phytochemical constituents in leaves and callus of Ficus deltoidea Jack var. kunstleri (King) Corner. Walailak J Sci Technol. 2014;12(5):431-9. https://doi.org/10.14456/WJST.2015.86.

11. Prasathkumar M, Anisha S, Dhrisya C, Becky R, Sadhasivam S. Therapeutic and pharmacological efficacy of selective Indian medicinal plants - a review. Phytomedicine Plus. 2021;1(2):100029. https://doi.org/10.1016/j. phyplu.2021.100029.

12. Kamal MSA, Ismail NH, Satar NA, Azis NA, Radjeni Z, Mohammad Noor HS, et al. Standardized ethanol-water extract of Ficus deltoidea angustifolia reduces blood pressure in spontaneously hypertensive rats. Clin Exp Hypertens. 2019;41(5):444-51. https://doi.org/10.1080/10641963.2018.1506467.

13. Al-koshab M, Alabsi AM, Bakri MM, Ali-Saeed R, Naicker MS. Antitumor activity of Ficus deltoidea extract on oral cancer: An in vivo study. J Oncol. 2020. https://doi.org/10.1155/2020/5490468.

14. Wang H, Vidyadaran S, Mohd Moklas MA, Baharuldin M. Inhibitory Activity of Ficus deltoidea var. trengganuensis aqueous extract on lipopolysaccharide-induced TNF-a production from microglia. Evid Based Complement Alternat Med. 2017. https://doi.org/10.1155/2017/2623163.

15. Nurdiana S, Mohd Idzham AZ, Zanariah A. Mohd Luqman hakim MN. Effect of Ficus deltoidea leaves extracts on blood clotting, sperm quality and testosterone level in alloxan-induced male diabetic rats. Int J Pharm Sci Rev Res. 2012;13(1):111-4.

16. Nur Ajeerah S, Nooraain H, Nurdiana S. Ficus deltoidea ethanolic leaves extract improves hormonal balance among letrozole induced polycystic ovarian syndrome (PCOS) rats. Malays Appl Biol. 2017;46(1):147-52.

17. Nurdiana S, Goh YM, Hafandi A, Dom SM, Nur Syimal'ain A, Noor Syaffinaz $\mathrm{NM}$, et al. Improvement of spatial learning and memory, cortical gyrification patterns and brain oxidative stress markers in diabetic rats treated with Ficus deltoidea leaf extract and vitexin. J Tradit Complement Med. 2017;8(1):190-202. https://doi.org/10.1016/j.jtcme.2017.05.006.

18. Nurdiana S, Goh YM, Ahmad H, Dom SM, Syimal'ain Azmi N, Noor Mohamad Zin NS, Ebrahimi M. Changes in pancreatic histology, insulin secretion and oxidative status in diabetic rats following treatment with Ficus deltoidea and vitexin. BMC Complement Altern Med. 2017;17;1; https://doi.org/10.1186/s12906-017-1762-8.

19. Samsulrizal N, Goh YM, Ahmad H, Md Dom S, Azmi NS. Noor Mohamad zin NS, Ebrahimi M. Ficus deltoidea promotes bone formation in streptozotocin-induced diabetic rats. Pharm Biol. 2021;59(1):66-73. https://doi. org/10.1080/13880209.2020.1865411.

20. Abubakar AR, Haque M. Preparation of medicinal plants: basic extraction and fractionation procedures for experimental purposes. J Pharm Bioallied Sci. 2020;12(1):1-10. https://doi.org/10.4103/jpbs.JPBS_175_19.

21. Farsi E, Ahmad M, Hor SY, Ahamed MB, Yam MF, Asmawi MŽ, et al. Standardized extract of Ficus deltoidea stimulates insulin secretion and blocks hepatic glucose production by regulating the expression of glucose-metabolic genes in streptozitocin-induced diabetic rats. BMC Complement Altern Med. 2014;14. https://doi.org/10.1186/1472-6882-14-220.

22. Nair $A B$, Jacob $S$. A simple practice guide for dose conversion between animals and human. J Basic Clin Pharm. 2016;7(2):27-31. https://doi.org/ 10.4103/0976-0105.177703. 
23. Karateke A, Dokuyucu R, Dogan H, Ozgur T, Tas ZA, Tutuk O, et al. Investigation of therapeutic effects of erdosteine on polycystic ovary syndrome in a rat model. Med Princ Pract. 2018;27(6):515-22. https://doi.org/10. $1159 / 000494300$.

24. Kakadia N, Patel P, Deshpande S, Shah G. Effect of Vitex negundo L. seeds in letrozole induced polycystic ovarian syndrome. J Tradit Complement Med. 2018;9(4):336-45. https://doi.org/10.1016/j.jtcme.2018. 03.001

25. Bandariyan E, Mogheiseh A, Ahmadi A. The effect of lutein and Urtica dioica extract on in vitro production of embryo and oxidative status in polycystic ovary syndrome in a model of mice. BMC Complement Med Ther. 2021;21:55. https://doi.org/10.1186/s12906-021-03229-x.

26. Carani A, Dipti N. Sitagliptin recuperates oxidative stress and inflammatory cytokine expression in ovary of PCOS rats. J Drug Deliv Ther. 2019;9 Suppl 4:244-51. https://doi.org/10.22270/jddt.v9i4-s.3261.

27. Chu W, Zhai J, Xu J, Li S, Li W, Chen ZJ, et al. Continuous light-induced PCOS-like changes in reproduction, metabolism, and gut microbiota in Sprague-Dawley rats. Front Microbiol. 2020;10:3145. https://doi.org/10. 3389/fmicb.2019.03145.

28. Sato J, Nasu M, Tsuchitani M. Comparative histopathology of the estrous or menstrual cycle in laboratory animals. J Toxicol Pathol. 2016;29(3):15562. https://doi.org/10.1293/tox.2016-0021.

29. Mamikutty N, Thent ZC, Sapri SR, Sahruddin NN, Mohd Yusof MR, Haji SF. The establishment of metabolic syndrome model by induction of fructose drinking water in male Wistar rats. Biomed Res Int. 2014. https://doi. org/10.1155/2014/263897.

30. Arika WM, Kibiti CM, Njagi JM, Ngugi MP. Modulation of cognition: the role of gnidia glauca on spatial learning and memory retention in highfat diet-induced obese rats. Neural Plasticity. 2019. https://doi.org/10. $1155 / 2019 / 2867058$.

31. Shen $H R, X u X, L i X L$. Berberine exerts a protective effect on rats with polycystic ovary syndrome by inhibiting the inflammatory response and cell apoptosis. Reprod Biol Endocrinol. 2021;19:3. https://doi.org/10.1186/ s12958-020-00684-y.

32. Mvondo MA, Mzemdem Tsoplfack Fl, Awounfack CF, Njamen D. The leaf aqueous extract of Myrianthus arboreus P. Beauv. (Cecropiaceae) improved letrozole-induced polycystic ovarian syndrome associated conditions and infertility in female Wistar rats. BMC Complement Med Ther. 2020;20:275. https://doi.org/10.1186/s12906-020-03070-8.

33. Salehi R, Mazier HL, Nivet AL, Reunov AA, Lima P, Wang Q, et al. Ovarian mitochondrial dynamics and cell fate regulation in an androgen-induced rat model of polycystic ovarian syndrome. Sci Rep. 2020;10:1021. https:// doi.org/10.1038/s41598-020-57672-w.

34. Wu C, Lin F, Qiu S, Jiang Z. The characterization of obese polycystic ovary syndrome rat model suitable for exercise intervention. PLoS One. 2014;9:6. https://doi.org/10.1371/journal.pone.0099155.

35. Ghowsi M, Khazali H, Sisakhtnezhad S. The effect of resveratrol on oxidative stress in the liver and serum of a rat model of polycystic ovary syndrome: an experimental study. Int J Reprod Biomed. 2018;16(3):149-58.

36. Wang MX, Yin Q, Xu X. A rat model of polycystic ovary syndrome with insulin resistance induced by letrozole combined with high fat diet. Med Sci Monit. 2020;26. https://doi.org/10.12659/MSM.922136.

37. Rojas J, Chávez M, Olivar L, Rojas M, Morillo J, Mejías J, et al. Polycystic ovary syndrome, insulin resistance, and obesity: navigating the pathophysiologic labyrinth. Int J Reprod Med. 2014;719050. https://doi.org/10 1155/2014/719050.

38. Kim CH, Chon SJ, Lee SH. Effects of lifestyle modification in polycystic ovary syndrome compared to metformin only or metformin addition: a systematic review and meta-analysis. Sci Rep. 2020;10:7802. https://doi. org/10.1038/s41598-020-64776-W

39. Dou L, Zheng Y, Li L, Gui X, Chen Y, Yu M, et al. The effect of cinnamon on polycystic ovary syndrome in a mouse model. Reprod Biol Endocrinol. 2018;16:99. https://doi.org/10.1186/s12958-018-0418-y.

40. Haida Z, Syahida A, Ariff SM, Maziah M, Hakiman M. Factors affecting cell biomass and flavonoid production of Ficus deltoidea var kunstleri in cell suspension culture system. Sci Rep. 2019;9:9533. https://doi.org/10.1038/ s41598-019-46042-w.
41. Kao YH, Hiipakka RA, Liao S. Modulation of endocrine systems and food intake by green tea epigallocatechin gallate. Endocrinology. 2000;141(3):980-7. https://doi.org/10.1210/endo.141.3.7368.

42. Kobayashi Y, Suzuki M, Satsu H, Arai S, Hara Y, Suzuki K, et al. Green tea polyphenols inhibit the sodium-dependent glucose transporter of intestinal epithelial cells by a competitive mechanism. J Agric Food Chem. 2000;48(11):5618-23. https://doi.org/10.1021/jf0006832.

43. Rocha T, Crespo RP, Yance V, Hayashida SA, Baracat EC, Carvalho F, et al. Persistent poor metabolic profile in postmenopausal women with ovarian hyperandrogenism after testosterone level normalization. J Endocrine Soc. 2019;3(5):1087-96. https://doi.org/10.1210/js.2018-00405.

44. Geller DH, Pacaud D, Gordon CM, Misra M. State of the art review: emerging therapies: the use of insulin sensitizers in the treatment of adolescents with polycystic ovary syndrome (PCOS). Int J Pediatr Endocrinol. 2011;9. https://doi.org/10.1186/1687-9856-2011-9.

45. Ndeingang EC, Defo Deeh PB, Watcho P, Kamanyi A. Phyllanthus muellerianus (Euphorbiaceae) restores ovarian functions in letrozole-induced polycystic ovarian syndrome in rats. Evid Based Complement Alternat Med. 2019. https://doi.org/10.1155/2019/2965821.

46. Wasan KM, Goss PE, Pritchard PH, Shepherd L, Palmer MJ, Liu S, et al. The influence of letrozole on serum lipid concentrations in postmenopausal women with primary breast cancer who have completed 5 years of adjuvant tamoxifen (NCIC CTG MA.17L). Ann Oncol. 2005;16(5):707-15. https://doi.org/10.1093/annonc/mdi158.

47. Lamb HM, Adkins JC. Letrozole: a review of its use in postmenopausal women with advanced breast cancer. Drugs. 1998;56(6):1125-40. https:// doi.org/10.2165/00003495-199856060-00020.

48. Fontaine C, Meulemans A, Huizing M, Collen C, Kaufman L, De Mey J, et al. Tolerance of adjuvant letrozole outside of clinical trials. Breast. 2008;17(4):376-81. https://doi.org/10.1016/j.breast.2008.02.006.

49. Ariadi A, Jamsari J, Yanwirasti Y, Siregar M, Yusrawati Y. Correlation between estrogen levels with lipid profile in menopause women in west Sumatera. Open Access Macedonian J Med Sci. 2019;7(13):2084-7. https://doi.org/10.3889/oamjms.2019.625.

50. Bhagya V, Hemalatha NR, Veeranna HB, Banu V. Serum lipid profile in prepubertal, reproductive, and postmenopausal women. Int J Biol Med Res. 2011;2(3):639-42.

51. Abdel-Rahman R, Ezzat S, Ogaly H, Abd-Elsalam R, Hessin A, Fekry M, et al. Ficus deltoidea extract down-regulates protein tyrosine phosphatase 1B expression in a rat model of type 2 diabetes mellitus: a new insight into its antidiabetic mechanism. J Nutr Sci. 2020;9. https://doi.org/10.1017/jns. 2019.40.

52. Kalman DS, Schwartz HI, Feldman S, Krieger DR. Efficacy and safety of Elaeis guineensis and Ficus deltoidea leaf extracts in adults with prediabetes. Nutr J. 2013;12:36. https://doi.org/10.1186/1475-2891-12-36.

53. Wang S, He G, Chen M, Zuo T, Xu W, Liu X. The role of antioxidant enzymes in the ovaries. Oxidative Med Cell Longev. 2017. https://doi.org/ 10.1155/2017/4371714.

54. Shahrokhi SA, Naeini AA. The association between dietary antioxidants, oxidative stress markers, abdominal obesity and poly-cystic ovary syndrome: a case control study. J Obstet Gynaecol. 2020;40(1):77-82. https:// doi.org/10.1080/01443615.2019.1603215.

55. Murri M, Luque-Ramírez M, Insenser M, Ojeda-Ojeda M, Escobar-Morreale HF. Circulating markers of oxidative stress and polycystic ovary syndrome (PCOS): a systematic review and meta-analysis. Hum Reprod Update. 2013;19(3):268-88. https://doi.org/10.1093/humupd/dms059.

56. Carbone MC, Tatone C, Delle Monache S, Marci R, Caserta D, Colonna R, et al. Antioxidant enzymatic defences in human follicular fluid: characterization and age-dependent changes. Mol Hum Reprod. 2003;9(11):63943. https://doi.org/10.1093/molehr/gag090.

57. Bracho GS, Altamirano GA, Kass L, Luque EH, Bosquiazzo VL. Hyperandrogenism induces histo-architectural changes in the rat uterus. Reprod Sci. 2019;26(5):657-68. https://doi.org/10.1177/1933719118783881.

58. Furat Rencber S, Kurnaz Ozbek S, Eraldemır C, Sezer Z, Kum T, Ceylan $S$, et al. Effect of resveratrol and metformin on ovarian reserve and ultrastructure in PCOS: an experimental study. J Ovarian Res. 2018;11:55. https://doi.org/10.1186/s13048-018-0427-7. 
59. Alves ED, Bonfá ALO, Pigatto GR, Anselmo-Franci JA, Achcar JA, Parizotto $N A$, et al. Photobiomodulation can improve ovarian folliculogenesis and steroidogenesis in polycystic ovary syndrome-induced rats. FASEB J. 2020;34. https://doi.org/10.1096/fasebj.2020.34.s1.04430

60. Sherafatmanesh S, Ekramzadeh M, Tanideh N, Golmakani MT, Koohpeyma F. The effects of thylakoid-rich spinach extract and aqueous extract of caraway (Carum carvi L.) in letrozole-induced polycystic ovarian syndrome rats. BMC Complement Med Ther. 2020;20:249. https://doi.org/10. 1186/s12906-020-03044-w.

61. Adam Z, Khamis S, Ismail A, Hamid M. Ficus deltoidea: a potential alternative medicine for diabetes mellitus. Evid Based Complement Alternat Med. 2012;2012:632763. https://doi.org/10.1155/2012/632763.

62. Reverchon M, Maillard V, Froment P, Ramé C, Dupont J. Adiponectin and resistin: a role in the reproductive functions? Med Sci (Paris). 2013;29(4):417-24. https://doi.org/10.1051/medsci/2013294016.

\section{Publisher's Note}

Springer Nature remains neutral with regard to jurisdictional claims in published maps and institutional affiliations.

- fast, convenient online submission

- thorough peer review by experienced researchers in your field

- rapid publication on acceptance

- support for research data, including large and complex data types

- gold Open Access which fosters wider collaboration and increased citations

- maximum visibility for your research: over $100 \mathrm{M}$ website views per year

At BMC, research is always in progress.

Learn more biomedcentral.com/submissions 